\title{
Pengendalian Pencucian Senyawa Nitrat Guna Meningkatkan Produktivitas Lahan Marginal Pantai Kulon Progo DIY
}

DOI 10.18196/pt.2016.056.46-57

\section{Gunawan Budiyanto}

Program Studi Agroteknologi, Fakultas Pertanian, Universitas Muhammadiyah Yogyakarta, Jl. Lingkar Selatan, Kasihan, Bantul, Yogyakarta 55183; Email: goenb@yahoo.com

\begin{abstract}
ABSTRAK
Penelitian dalam skala laboratorium dilaksanakan untuk menentukan efek pemberian bahan organik dalam mengurangi laju pencucian nitrat di lahan pasir pantai Kulon Progo, Yogyakarta, yang dilaksanakan pada bulan Februari hingga Agustus 2014. Penelitian ini dirancang menggunakan Rancangan Acak Lengkap faktorial. Faktor pertama yaitu rasio kotoran sapi dengan jerami (1:1; 1:2; 1:3), dan faktor kedua yaitu Pupuk N (Urea dan ZA). Hasil menunjukan bahwa (a) Urea sebagai sumber pupuk N, cocok diaplikasikan di lahan pasir pantai dan (b) Bahan organik dengan rasio kotoran sapi dan jerami (1:1) dapat menurunkan laju pencucian nitrat di lahan pasir pantai Kulon Progo.

Kata Kunci: Lahan pasir pantai, Rasio kotoran sapi, Jerami, Fraksi N-tanah
\end{abstract}

\begin{abstract}
A laboratory experiment was conducted to determine the organic matter in reducing Nitrate leaching of coastal sandy soil of Kulon Progo, Yogyakarta, done from February up to August 2014. This experiment was arranged in a factorial completely randomized design. The first factor were ratio of cow dung and rice straw (1:1; 1:2 and 1:3), and the second factor were N fertilizer (urea and ZA). The result showed (a) Urea as source of N-fertilizer was more suitable to apply in coastal sandy soil and (b) Organic matter with ratio of cow dung and rice straw (1:1) was able to decrease nitrate leaching of coastal sandy soil of Kulon Progo.

Keywords: Coastal Sandy Land, Ratio of Cow Dung, Rice-Straw, Fraction of N-Soil
\end{abstract}

\section{PENDAHULUAN}

Kabupaten Kulon Progo merupakan salah satu dari 5 Pemerintah Daerah Tingkat II yang ada di Provinsi Daerah Istimewa Yogyakarta. Secara geografis kabupaten ini terletak antara 7038'3" - 7०59'3" Lintang Selatan dan 110¹'37" - 110 16’26" Bujur Timur, yang dibatasi Provinsi Jawa Tengah di sebelah Barat Laut, Sungai Progo di sebelah Timur dan Samudra Indonesia di sebelah Selatan (Pemerintah Daerah Kulon Progo,DIY.,2003).

Pembangunan yang lebih didasarkan kepada motif ekonomi mengakibatkan lahan pertanian dapat berkurang karena berubah menjadi lahan - lahan non-pertanian seperti kompleks perumahan, pabrik dan infrastruktur kota lainnya. Sungkono (1997) menyatakan bahwa perubahan lahan sawah menjadi lahan nonpertanian di Daerah Istimewa Yogyakarta ratarata mencapai 1.300 hektar per tahunnya. Sementara di Kabupaten Kulon Progo, dari tahun 2003 sampai dengan 2007 telah terjadi penurunan luas sawah sebesar 671 hektar (BPS Kulon Progo, 2008). Otonomi daerah menyebabkan pembangunan di bidang ekonomi dan sarana transportasi telah dapat menjangkau kota Kecamatan. Jaringan transportasi yang melewati kawasan - kawasan subur tersebut bukan lagi berdampak melancarkan 
pengangkutan hasil pertanian, tetapi justru mengakibatkan alih fungsi lahan - lahan produktif menjadi lahan non-pertanian. Pada akhirnya ekstensifikasi pertanian ataupun pengembangan program-program pertanian mengalami kekurangan sediaan lahan.

Kabupaten Kulon Progo memiliki potensi lahan pasir pantai yaitu seluas $29,3716 \mathrm{~km}^{2}$ atau 2.937,16 hektar terhampar sebagai dataran aluvial di sepanjang pantai Selatan mulai dari muara Sungai Progo sampai batas Kabupaten Purworejo sejauh kurang lebih 20 km., meliputi sisi selatan wilayah Kecamatan Galur, Panjatan, Wates dan Temon Kulon Progo. Dataran aluvial pantai tersebut merupakan dataran lahan pasir pantai yang terbentuk dari materi vulkanik yang secara deflasif dan akumulatif dibawa angin (Pemerintah Daerah Kulon Progo DIY., 2003; Darmawijaya, 1992). Bahan ini bercampur dengan bahan aluvial Gunung Merapi yang dibawa Sungai Progo dan kemudian dihamparkan oleh air laut dan angin membentuk tanah Regosol Pantai yang bersifat porus, mudah diolah dengan gaya menyimpan air rendah dan permeabilitas cepat sampai sangat cepat. Dataran aluvial pantai ini sebagian besar berasal dari endapan materi volkanik Gunung Merapi. Fisiografi wilayah terdiri atas hamparan gumuk pasir (sand dunes), bukit pasir (sand ridge) dan dataran lagoon yang berada di balik bukit pasir. Lahan datar pantai Bugel didominasi oleh tanah pasir yang distribusinya ke arah daratan (pedalaman) dipengaruhi oleh hembusan angin laut.

Menurut Sudihardjo (2000) lahan pantai selatan Daerah Istimewa Yogyakarta masuk dalam kriteria lahan tidak sesuai atau sesuai marginal untuk komoditi tanaman pangan dan sayuran. Pengelolaan lahan marginal pada umumnya dimulai dari perbaikan faktor pembatas yang ada, yaitu gerakan air gravitasi dan pelindian nitrat. Permeabilitas yang cepat sampai sangat cepat diakibatkan oleh volume ruang pori makro yang lebih besar dibanding ruang pori mikro. Sebagai akibatnya, tanah pasir pantai cenderung meloloskan air sehingga tidak dapat menyimpan air dalam waktu lama. Kondisi semacam ini tidak menguntungkan bagi setiap upaya pemupukan yang cenderung membutuhkan air sebagai pelarut hara nitrogen yang dikandungnya. Di sisi lain, pada saat terjadi kelebihan air di ruang pori tanahnya, maka sejumlah besar air yang dikandung tanah tersebut akan segera bergerak ke bawah karena pengaruh gaya gravitasi. Gerakan air ke bawah ini dapat membawa hara nitrogen yang berasal dari pupuk keluar dari zona akar, dan sebagai akibatnya, pemupukan menjadi tidak efisien. Lebih lanjut Bahr,dkk. (2006) dan Wolkowski, dkk. (2006) menyatakan bahwa pelindian nitrat lebih sering terjadi dalam tanah pasiran dan menjadi masalah di kawasan beriklim kering.

Salah satu cara yang ditempuh untuk meningkatkan produktivitas lahan - lahan marginal khususnya lahan pasir pantai adalah dengan menambah sumber - sumber nitrogen terutama pupuk organik dan pupuk an-organik lainnya. Di satu sisi bahan organik diharapkan dapat menciptakan kompleks koloid organik dan meningkatkan kemampuan tanah dalam mengikat air serta meningkatkan kelarutan pupuk an-organik yang diberikan. FAO (2005) menyatakan bahwa penambahan bahan organik ke dalam tanah dapat meningkatkan jumlah pori mikro dan bahkan beberapa jenis bahan organik tertentu dapat mengikat air dua puluh kali lipat beratnya. Atas dasar hal ini, pemberian bahan organik diharapkan dapat memperbaiki kelemahan sifat lahan pasir. Pemberian bahan 
organik ditujukan menurunkan laju gerakan air gravitasi sehingga dapat menurunkan proses pelindian nitrat dan meningkatkan fiksasi ion ammonium dalam kompleks koloid organik tanah yang akhirnya dapat menunda proses nitrifikasi.

Nitrogen merupakan salah satu unsur dari tiga unsur utama tanaman yaitu nitrogen, fosfor dan kalium. Di dalam tanah, nitrogen merupakan unsur yang labil, karena keberadaannya berada dalam antara proses mineralisasi dan immobilisasi. Nitrogen anorganik yang dihasilkan proses mineralisasi akan mengalami proses nitrifikasi, denitrifikasi dan volatilisasi. Nitrifikasi merupakan proses transformasi ion ammonium menjadi ion nitrat yang selalu berada dalam larutan tanah. White dan Reddy (2003) menyatakan bahwa nitrifikasi adalah proses oksidasi biologi ion $\mathrm{NH}_{4}^{+}$menjadi $\mathrm{NO}_{2}$ - dan $\mathrm{NO}_{3}$ yang melibatkan bakteri ototrof. Wolkowski, dkk (2006) menambahkan bahwa nitrifikasi akan terjadi jika $\mathrm{N}$-ammonium dimasukkan ke dalam tanah yang bertemperatur hangat dan cukup tersedia air. Ion nitrat yang bermuatan negatif tidak diikat oleh partikel tanah dan akan segera terlindi ketika terdapat air yang bergerak melalui tanah.

Gehl,dkk. (2005) menyatakan bahwa efisiensi manajemen nitrogen menjadi penting untuk meminimalisir kontribusi pertanian dalam menyebabkan polusi $\mathrm{NO}_{3}$ air tanah. Kegagalan lahan pasir dalam menyediakan larutan tanah menyebabkan kendala serapan unsur hara nitrogen, sementara pada kondisi air berlebih ion nitrat akan terbawa air gravitasi ke luar zona akar sebagaimana pendapat Saito (1991) bahwa kelebihan nitrogen yang tidak diserap tanaman dapat tercuci ke luar zona akar. Permeabilitas yang cepat sampai sangat cepat menjadikan setiap upaya pemupukan selalu mengalami efisiensi yang rendah terutama pemupukan unsur nitrogen. Schmitt, dkk.( 1994) dan Nakamura, dkk., (2004) menyatakan bahwa pemberian pupuk nitrogen dalam frekuensi lebih banyak (lebih dari 3 kali) sangat dianjurkan karena terbukti dapat mengurangi in-efisiensi pemupukan, tetapi dengan frekuensi lebih banyak dapat menimbulkan beban biaya tenaga kerja. Pemanfaatan lahan pasir pantai yang dihubungkan dengan aplikasi pupuk nitrogen selalu dihadapkan pada masalah rendahnya efisiensi pemupukan yang disebabkan oleh (a) kekurangmampuan tanahnya dalam menyediakan air bagi proses serapan nitrogen oleh tanaman dan (b) kondisi aerasi tanahnya yang menyebabkan terjadinya proses nitrifikasi pupuk nitrogen dan kehilangan nitrogen lewat proses pelindian nitrat.

Manajemen nitrogen dalam tanah merupakan upaya untuk mengendalikan ketersediaan hara nitrogen dalam larutan tanah agar dicapai efisiensi serapan hara nitrogen dan memberikan hasil tanaman yang diharapkan. Pengendalian status hara nitrogen dalam larutan tanah dapat dilakukan dengan menghambat proses perubahan $\mathrm{N}$-ammonium menjadi $\mathrm{N}$ nitrat dengan memasukkan bahan organik dengan rasio $\mathrm{C} / \mathrm{N}$ lebih besar 40 , serta mereduksi pencucian nitrat (Baker, 2001; Rahn,dkk., 2003; dan Bauder, dkk., 2006). Berdasarkan hal - hal tersebut, guna meningkatkan produktivitasnya, lahan pasir pantai Selatan Kulon Progo Daerah Istimewa Yogyakarta dapat ditempuh melalui manajemen nitrogen tanah yang dititikberatkan kepada upaya - upaya konservasi nitrat di dalam tanah. Pengendalian ketersediaan hara nitrogen dalam larutan tanah dan penurunan laju pelindian senyawa nitrat melalui gerakan air gravitasi 
dapat dilakukan dengan penambahan bahan organik ke dalam tanah.

\section{BAHAN DAN METODE}

Penelitian dilaksanakan menggunakan metode percobaan laboratorium disusun dalam rancangan acak lengkap faktorial (Factorial Completlely Randomized Design) (Gomez and Gomez, 1994). Faktor pertama adalah bahan organik (B) terdiri dari empat level perlakuan yaitu, tanpa perlakuan bahan organik (b0), bahan organik dengan perbandingan kotoran sapi-jerami padi 1:1 (b1), bahan organik dengan perbandingan kotoran sapi-jerami padi 1:2 (b2) dan bahan organik dengan perbandingan kotoran sapi-jerami padi 1:3 (b3), dengan masing - masing dosis 10 t hektar (Hasanudin, 2003). Faktor kedua adalah pupuk nitrogen (N) terdiri dari dua level perlakuan yaitu, pupuk $\mathrm{N}$ yang bersumber dari urea (n1) dan pupuk $\mathrm{N}$ yang bersumber dari ZA (n2) dengan dosis masing - masing $135 \mathrm{~kg} \mathrm{~N}$ hektar (Sutoro, dkk., 1988).

\section{TATA LAKSANA PERCOBAAN}

Sampel tanah diambil secara komposit pada kedalaman $30 \mathrm{~cm}$, dari lokasi yang berupa dataran aluvial pantai Selatan Kulon Progo Daerah Istimewa Yogyakarta. Sampel tanah dari lapangan tersebut dicampur rata dan dikeringanginkan selama 7-10 hari. Setelah masa pengeringan selesai, seluruh sampel tanah tersebut disaring dengan saringan berdiameter 2 mm., kemudian ditimbang seberat 948,76 g sampel tanah kering mutlak (setara dengan 950,28 g sampel tanah kering angin) sebanyak 4 buah sampel tanah. Seberat $160 \mathrm{~g}$ atau setara dengan berat $10 \mathrm{t}$ hektar pupuk bahan organik dengan perbandingan kotoran sapi-jerami padi sesuai dengan perlakuan yang direncanakan, dicampurkan dengan sampel tanah yang telah dipersiapkan. Setelah pekerjaan ini selesai, seberat $4 \mathrm{~g}$ pupuk SP-36 (setara dengan $90 \mathrm{~kg}$. $\mathrm{P}_{2} \mathrm{O}_{5}$ hektar) dan $1,92 \mathrm{~g}$ pupuk $\mathrm{KCl}$ (setara dengan $60 \mathrm{~kg} . \mathrm{K}_{2} \mathrm{O}$ hektar) dicampurkan secara merata ke dalam setiap sampel tanah, kemudian sampel - sampel tanah ini dimasukkan ke dalam piranti perkolator yang bergaris tengah $5 \mathrm{~cm}$. dan tinggi $40 \mathrm{~cm}$. (modifikasi alat Nakamura, dkk.,2004) dan diinkubasikan selama satu minggu dalam kondisi kapasitas lapangan (Polprasert,1996). Pekerjaan ini diulang 3 kali sehingga didapatkan 12 uniton percobaan. Semua pekerjaan ini diulang lagi, sehingga didapatkan 2 kelompok sampel tanah yang masing - masing terdiri dari 12 uniton percobaan.

Setelah masa inkubasi selesai, ke dalam masing - masing perkolator (kelompok sampel tanah pertama) ditambahkan $135 \mathrm{~kg} \mathrm{~N}$ hektar yang bersumber dari pupuk Urea. Pekerjaan ini diulang lagi untuk pemupukan $135 \mathrm{~kg} \mathrm{~N}$ hektar yang bersumber dari pupuk ZA (kelompok sampel tanah kedua). Penambahan 100 ml. air bebas ion ke dalam masing-masing perkolator dilaksanakan setiap hari melalui tetesan air dengan kecepatan 1 tetes/detik (Rowell, 1994). Air perkolasi yang keluar dari piranti perkolator ditampung, dan ditetapkan konsentrasi ion $\mathrm{NO}_{3}$ setiap minggunya selama 6 minggu pengamatan, dan pada minggu ke 6 juga dilaksanakan analisis $\mathrm{N}$-total tanah.

\section{HASIL DAN PEMBAHASAN}

Hasil penetapan variabel respon disajikan dalam Tabel 1. Tabel 1 menunjukkan bahwa tidak terdapat interaksi antara komposisi bahan organik dengan pupuk N. Sumber pupuk N memberikan pengaruh berbeda nyata kepada total lindian nitrat. ZA sebagai sumber pupuk $\mathrm{N}$ 
Tabel 1. Hasil Penetapan Lindian Nitrat dan N-total.

\begin{tabular}{lll}
\hline $\begin{array}{l}\text { Perlakuan } \\
\text { kot sapi : jerami padi }\end{array}$ & $\begin{array}{l}\text { Total lindian } \\
\text { nitrat }(\mathrm{mg} \mathrm{N})\end{array}$ & $\begin{array}{l}\text { N-total tanah } \\
\left(\mathrm{g} \mathrm{N} \mathrm{kg}^{-1}\right)\end{array}$ \\
\hline tanpa bahan organik (b0) & $77,05 \mathrm{a}$ & $0,0928 \mathrm{c}$ \\
perbandingan 1:1 (b1) & $45,24 \mathrm{a}$ & $0,5685 \mathrm{a}$ \\
perbandingan 1:2 (b2) & $52,66 \mathrm{a}$ & $0,4375 \mathrm{~b}$ \\
perbandingan 1:3 (b3) & $45,39 \mathrm{a}$ & $0,3768 \mathrm{~b}$ \\
Urea (n1) & $24,22 \mathrm{~B}$ & $0,3753 \mathrm{~A}$ \\
ZA (n2) & $85,95 \mathrm{~A}$ & $0,3625 \mathrm{~A}$ \\
\hline
\end{tabular}

Keterangan:

Rerata yang diikuti oleh huruf yang sama (huruf kecil atau huruf besar) menunjukkan tidak berbeda nyata berdasarkan UJGD 5\%.

menghasilkan total lindian nitrat lebih besar dibanding urea. Hal ini menunjukkan bahwa urea sebagai sumber $\mathrm{N}$ lebih sesuai diaplikasikan di tanah pasir pantai. Hasil analisis terhadap tanah yang dipupuk urea dan ZA dan pengaruhnya terhadap lindian nitrat setiap minggu disajikan dalam Tabel 2 .

Tabel 2 menunjukkan bahwa tanah yang mendapat pupuk $\mathrm{N}$ menghasilkan keragaman jumlah nitrat terlindi. Tanah yang tidak diberi bahan organik menunjukkan bahwa puncak pelindian nitrat terjadi pada minggu pertama inkubasi. Sementara variasi bobot lindian nitrat setiap minggu disajikan dalam Gambar 1 dan 2 berikut:

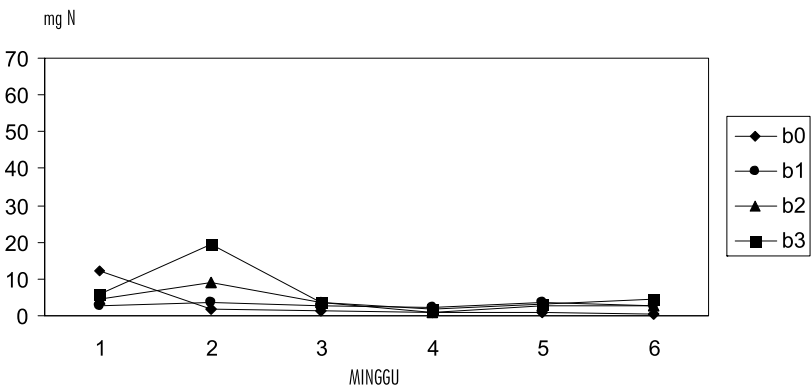

Gambar 1. Pengaruh bahan organik dan urea terhadap nitrat terlindi.

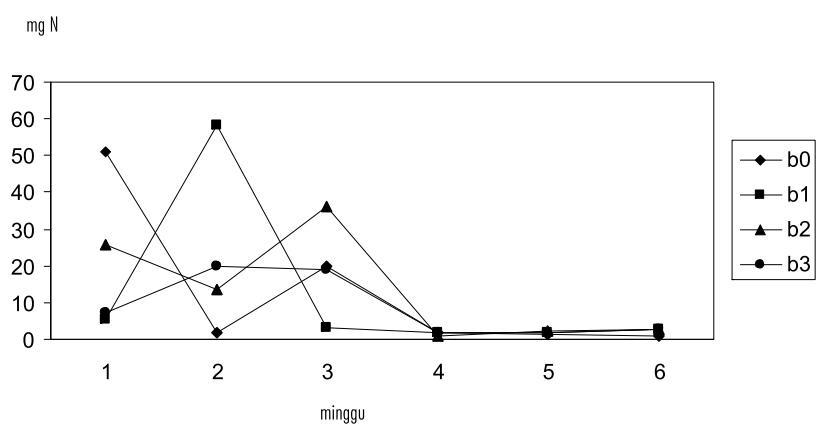

Gambar 2. Pengaruh bahan organik dan ZA terhadap nitrat terlindi.

Gambar 1 di atas menunjukkan bahwa puncak pelindian ion nitrat dalam tanah yang diberi Urea dan tidak diberi bahan organik (b0) terjadi pada minggu ke-1 yaitu sebesar 11,994 mg N, dan pada minggu - minggu berikutnya pelindian ion nitrat mengalami penurunan. Belliturk dan Saglam (2005) menyatakan bahwa pupuk urea yang dimasukkan ke dalam tanah dan diinkubasikan selama 14 hari mengalami hidrolisis cepat mulai hari ke-1 sampai dengan hari ke-7. Urea merupakan ikatan senyawa karbon yang dapat melepaskan $\mathrm{CO}_{2}$ pada saat terhidrolisis. Batjes dan Bridges (1992) menyatakan bahwa proses nitrifikasi terdiri atas ototrof nitrifikasi dan heterotrof nitrifikasi.

Pelepasan $\mathrm{CO}_{2}$ ini dapat digunakan oleh bakteri ototrof (Nitrosomonas dan Nitrobacter) sebagai sumber karbon dalam proses biologi pengubahan $\mathrm{NH}_{4}^{+}$menjadi $\mathrm{NO}_{3}$. Sementara puncak pelindian ion nitrat dalam tanah yang diperlakukan dengan bahan organik pada berbagai perbandingan kotoran sapi-jerami padi (b1, b2 dan b3) rata - rata terjadi pada minggu ke-2, yaitu masing sebesar 3,679 mg N (b1), 9,246 mg N (b2) dan 19,463 mg N (b3), selanjutnya mengalami penurunan sampai minggu ke-4, dan mengalami sedikit kenaikan mulai minggu ke-5.

Perbedaan bobot jerami padi yang terdapat 
Tabel 2. Lindian Nitrat setiap minggu (mg N).

\begin{tabular}{|c|c|c|c|c|c|c|}
\hline \multirow[t]{2}{*}{ Perlakuan } & \multicolumn{6}{|c|}{$\begin{array}{l}\text { Lindian nitrat }(\mathrm{mg}) \text { minggu ke : } \\
\text { Urea }(\mathrm{nl})\end{array}$} \\
\hline & 1 & 2 & 3 & 4 & 5 & 6 \\
\hline bo & $11,994 a$ & 1,985 b & $1,237 a$ & $0,818 a$ & 0,891 a & $0,507 \mathrm{~b}$ \\
\hline bl & $2,736 c$ & $3,679 \mathrm{~b}$ & $2,504 a$ & $2,065 a$ & $3,509 a$ & $2,762 a b$ \\
\hline b2 & $4,474 b$ & $9,246 a b$ & 3,781 a & 1,026 a & $2,563 a$ & $2,849 a b$ \\
\hline \multirow[t]{2}{*}{ b3 } & $\begin{array}{l}5,817 \mathrm{ab} \\
Z \mathrm{ZA}(\mathrm{n} 2)\end{array}$ & 19,463 a & $3,388 a$ & 1,974 a & $3,146 a$ & 4,449 a \\
\hline & 1 & 2 & 3 & 4 & 5 & 6 \\
\hline bo & $51,009 a$ & 1,698 b & 20,077 a & 1,682 a & $1,399 a$ & $0,694 b$ \\
\hline bl & $5,252 b$ & 58,148 a & $3,305 b$ & 1,747 a & $1,894 a$ & $2,874 a$ \\
\hline b2 & $25,835 a b$ & $13,537 b$ & $36.062 a$ & $0,973 a$ & $2,116 a$ & $2,764 a$ \\
\hline b3 & $7,434 b$ & 19,762 b & 19,096 a & 1,671 a & $1,676 a$ & 2,911 a \\
\hline
\end{tabular}

Keterangan:

Rerata dalam kolom yang diikuti huruf yang sama menunjukkan tidak berbeda nyata berdasar UJGD 5\%.

dalam bahan organik disebabkan oleh perbedaan perbandingan antara kotoran sapi dan jerami padi yang terdapat dalam bahan oganik (1:1, 1:2 dan 1:3). Pembandingan puncak pelindian nitrat pada minggu ke-2 terutama untuk perlakuan b1, b2 dan b3, menunjukkan bahwa dengan bobot jerami padi yang semakin besar cenderung menghasilkan peningkatan pelindian nitrat. Hal ini sejalan dengan pendapat Sajjad, dkk. (2003) bahwa tingkat kehilangan nitrogen dalam bentuk nitrat akan terjadi lebih banyak dalam sampel tanah yang banyak mengandung sisa tanaman segar. Penambahan jerami ke dalam tanah dapat meningkatkan sumber C-organik. Sumber Corganik ini dapat digunakan bakteri heterotrof sebagai sumber karbon dan energi dalam mengubah $\mathrm{NH}_{4}^{+}$menjadi $\mathrm{NO}_{3}$ - (Batjes dan Bridges, 1992).

Pada minggu ke-2 perlakuan bahan organik dengan perbandingan kotoran sapi-jerami padi 1: 1 (b1) menghasilkan nitrat terlindi lebih rendah dibanding dengan perlakuan bahan organik dengan perbandingan kotoran sapijerami padi 1:2 (b2) dan perbandingan 1:3 (b3). Hal ini mengindikasikan bahwa proses nitrifikasi dalam tanah yang mendapatkan perlakuan bahan organik b2 dan b3 lebih besar dibanding tanah yang mendapatkan perlakuan bahan organik b1. Bahan organik sebesar 10 ton per hektar dalam perbandingan kotoran sapi dan jerami padi 1: 1, serta pelindian nitrat total yang cenderung lebih rendah, menunjukkan bahwa perbandingan kotoran sapi dan jerami padi ini merupakan kombinasi dua jenis sumber bahan organik yang paling ideal untuk diaplikasikan ke dalam tanah pasir pantai. Dengan perbandingan 1:1, telah cukup terdapat kotoran sapi sebagai penyumbang fraksi humus yang berperan meningkatkan kemampuan tanah mengikat air sehingga proses pelindian nitrat dapat dikurangi, dan sifat koloid fraksi humus yang mampu memfiksasi ion ammoium pupuk, sehingga terhindar dari proses nitrifikasi 
yang berlebihan.

Kemampuan fraksi humus dalam mengikat air ini juga disampaikan oleh Brady (2002) bahwa kemampuan humus dalam mengikat air dalam satuan massanya bisa mencapai 4 sampai 5 kali lebih besar dibanding mineral silikat liat. Jumlah kotoran sapi yang lebih besar (b1) dibandingkan dengan perlakuan lainnya (b2 dan b3), menunjukkan bahwa kotoran sapi sebagai sumber koloid organik mampu menciptakan kualitas situs fiksasi yang efektif dalam mempertahankan stabilitas ion ammonium dalam tanah.

Gambar 1 tersebut menjelaskan bahwasanya bahan organik dapat menunda proses nitrifikasi ion ammonium yang dilepas pupuk urea. Pemberian bahan organik secara nyata dapat meningkatkan kemampuan tanah dalam mengikat ion positif dan air. Penambahan bahan organik berarti menciptakan asosiasi ikatan antara partikel tanah dengan bahan organik, dan sifat koloid yang dimiliki bahan organik dapat menambah luas permukaan adhesifnya yang bermuatan negatif. Sifat koloid dari permukaan ini menyebabkan terjadinya fiksasi ion ammonium yang berasal dari proses hidrolisis Urea, sehingga untuk sementara waktu proses nitrifikasi dapat ditunda.

Sementara di sisi lain, pemberian bahan organik yang bersifat hidrofilik dapat meningkatkan kemampuan tanah pasir dalam mengikat air dan ini berarti kondisi aerasi (kadar oksigen) dikurangi, serta sebagai akibatnya proses oksidasi ion ammonium-Urea menjadi ion nitrat dapat diturunkan.

Soedarsono, dkk. (1997) telah meneliti peningkatan kandungan air dan penurunan kondisi aerob terhadap proses nitrifikasi. Hasil penelitian tersebut menyimpulkan bahwa ketiadaan oksigen dapat menghambat proses nitrifikasi dan menghentikan transformasi $\mathrm{NH}_{4}^{+}$ menjadi $\mathrm{NO}_{2}$ - dan $\mathrm{NO}_{3}$ : Walaupun demikian, pelindian nitrat setelah minggu ke-5 terutama dari tanah yang diberi bahan organik membuktikan bahwa proses mineralisasi bahan organik, terutama jerami padi yang ditambahkan telah terjadi, karena memang pada dasarnya bahan organik merupakan penyedia lambat hara nitrogen. Penelitian proses mineralisasi nitrogen berbagai bentuk sisa tanaman yang diberi sumber $\mathrm{NH}_{4}^{+}$telah dilakukan Kara (2000). Hasil penelitian tersebut menemukan bukti bahwa tanah yang diperlakukan dengan jerami padi dan sumber ammonium menghasilkan peningkatan mineralisasi nitrogen setelah diinkubasikan selama 30 hari. Proses mineralisasi bahan organik ini menyumbang ion ammonium dalam jumlah cukup ke dalam tanah yang akhirnya akan dioksidasikan secara bertahap menjadi ion nitrat lewat proses nitrifikasi. Peningkatan pelindian nitrat yang terjadi setelah minggu ke-5 ini dapat juga disebabkan oleh aktivitas bakteri heterotropik yang dapat mengubah $\mathrm{NH}_{4}^{+}$ menjadi $\mathrm{NO}_{3}$. Sebagaimana disampaikan oleh Batjes dan Bridges (1992) bahwa nitrifikasi heterotropik terjadi dalam kondisi aerob dan mikroorganisme menggunakan karbon organik sebagai sumber karbon dan energi.

Gambar 2 menyajikan pengaruh bahan organik pada berbagai perbandingan kotoran sapi-jerami padi terhadap pelindian nitrat dari tanah yang diberi pupuk ZA (ammonium sulfat). Puncak pelindian nitrat tanah yang diberi pupuk ZA dan tidak diberi perlakuan bahan organik (b0) terjadi pada minggu ke satu. Sementara pada tanah - tanah yang diberi perlakuan bahan organik menunjukkan kecenderungan yang berbeda. Tanah yang diberi perlakuan bahan organik pada perbandingan kotoran 
sapi-jerami padi 1:1 (b1) menunjukkan puncak pelindian nitrat terjadi pada minggu ke-2.

Tanah yang diberi perlakuan bahan organik pada perbandingan kotoran sapi-jerami padi 1:2 (b2) menunjukkan puncak pelindian nitrat terjadi pada minggu ke-3. Sementara tanah yang diberi perlakuan bahan organik pada perbandingan kotoran sapi-jerami padi 1:3 (b3), menunjukkan puncak pelindian nitrat terjadi pada minggu ke-2 dan ke-3. Hal ini terjadi diduga karena terdapatnya perbedaan ratio $\mathrm{C} / \mathrm{N}$ bahan organik yang digunakan. Bahan organik dengan ratio $\mathrm{C} / \mathrm{N}$ lebih besar mengakibatkan penurunan laju mineralisasi bahan organik dan sebagai akibatnya terdapat perbedaan pencapaian puncak pelindian. Hasil percobaan Rahn, dkk (2003) menunjukkan bahwa bahan amendemen tanah dengan ratio $\mathrm{C} / \mathrm{N}$ tinggi dapat menghambat laju mineralisasi $\mathrm{N}$ bersih. Lovett, dkk (2002) juga menyatakan bahwa ratio $\mathrm{C} / \mathrm{N}$ bahan organik tanah merupakan variabel penentu konsentrasi $\mathrm{NO}_{3}$ - dalam larutan tanah.

Walaupun tidak sebaik tanah pasir yang diberi perlakuan Urea, Gambar 2 juga memberikan informasi bahwa pemberian bahan organik ke dalam tanah yang mendapat pemupukan ZA dapat menunda proses pembentukan nitrat. Pada minggu ke-1 sampai dengan ke-4, terjadi variasi pengaruh perlakuan b1, b2 dan b3 terhadap tingkat pelindian nitrat, dan ini dapat disebabkan oleh perbedaan kandungan kotoran sapi dan jerami padi yang ada dalam masing - masing perlakuan bahan organik tersebut. Penundaan proses pembentukan nitrat (nitrifikasi) ini disebabkan oleh kompleks nitrogen organik yang terbentuk karena adanya ikatan antara bahan organik dengan nitrogen mineral. Sebagaimana disampaikan oleh Stevenson (1982) bahwa fiksasi nitrogen mineral dan bahan organik dapat terjadi pada kisaran $\mathrm{pH}$ tanah yang cukup besar. Pada $\mathrm{pH}$ di atas 7,0 akan terjadi fiksasi antara ammonia dan bahan organik, sedangkan pada $\mathrm{pH}$ antara 5,0 - 5,0 atau di bawahnya dapat terjadi fiksasi antara nitrit dan bahan organik. Perubahan $\mathrm{pH}$ ini dapat terjadi selama periode perombakan bahan organik.

Sebagaimana disampaikan oleh Polprasert (1996) bahwa proses perombakan aerob biasanya terjadi pada $\mathrm{pH}$ sekitar netral dan jarang terjadi dalam kondisi $\mathrm{pH}$ alkalin atau asam. Dalam beberapa hari periode perombakan an-aerob yang menghasilkan asam lemak yang mudah menguap, $\mathrm{pH}$ dapat turun, dan setelah periode ini $\mathrm{pH}$ kembali di sekitar $\mathrm{pH}$ netral yaitu pada saat asam - asam ini dikonversikan menjadi metan dan karbondioksida oleh bakteri pembentuk metan.

Pengaruh bahan organik dan pupuk N terhadap kandungan $\mathrm{N}$-total dalam perkolator disajikan dalam Tabel 1 di atas. Tabel ini menunjukkan bahwa tidak ada interaksi antara bahan organik dengan pupuk $\mathrm{N}$ terhadap kandungan N-total tanah. Bahan organik dengan perbandingan kotoran sapi dan jerami padi 1:1 (b1) menghasilkan kandungan $\mathrm{N}$-total tanah lebih tinggi dan berbeda nyata dengan perlakuan lainnya. Sementara sumber pupuk nitrogen yang diberikan dalam bentuk pupuk Urea (n1) dan ZA (n2) tidak berbeda nyata terhadap kandungan $\mathrm{N}$ total tanah.

Bahan organik (b1, b2 dan b3) merupakan perlakuan yang dibedakan dalam jumlah kotoran sapi dan jerami padi. Pemberian bahan organik dengan perbandingan kotoran sapi dan jerami padi 1:1 merupakan perlakuan dengan jumlah kotoran sapi paling banyak dibanding perlakuan lainnya, sedangkan dalam jumlah jerami padi, perlakuan b1 memiliki bobot jerami padi paling rendah dibanding perlakuan 
b2 dan b3. Perbedaan jumlah kotoran sapi dan jerami yang terdapat dalam bahan organik, menunjukkan bahwa perlakuan b1 dengan perbandingan kotoran sapi dan jerami padi 1:1 merupakan perbandingan paling baik untuk diaplikasikan ke dalam tanah pasir pantai. Di satu sisi perbandingan ini mampu mempertahankan kandungan nitrogen totalnya. Sementara di sisi lain, perlakuan b1 memiliki kandungan kotoran sapi lebih banyak dibanding perlakuan lain.

Kotoran sapi yang terdapat dalam bahan organik memiliki kandungan $\mathrm{N}$ total sebesar 0,89\%, sedangkan jerami padi memiliki kandungan $\mathrm{N}$ total sebesar 0,51\%. Faesal,dkk. (2006) menyatakan bahwa kotoran sapi mengandung $\mathrm{N}$ sebesar 1,1\%. Sementara Dobermann dan Fairhurst (2002) menyatakan bahwa jerami padi mengandung $\mathrm{N}$ sebesar 0,5$0,8 \%$. Berdasarkan hal ini perlakuan b1 yang memiliki bobot kotoran sapi lebih besar dibanding perlakuan b2 dan b3, pada akhirnya akan memiliki kandungan $\mathrm{N}$ total tanah lebih tinggi. Pembandingan kandungan N-total tanah yang merupakan akibat perlakuan pemberian bahan organik (b1, b2 dan b3) dengan tanah yang tidak diberi bahan organik (bo) menunjukkan bahwa pemberian bahan organik ke dalam tanah pasir pantai terbukti dapat menambah sumber nitrogen organik maupun nitrogen mineral.

Kotoran sapi maupun jerami padi yang terdapat dalam bahan organik keduanya merupakan sumber nitrogen dalam tanah. Hubungan kedua bahan organik ini dengan kandungan $\mathrm{N}$ total tanah setelah 6 minggu diinkubasikan disajikan dalam Gambar 3.

Gambar 3 memperlihatkan bahwa baik kotoran sapi maupun jerami padi yang terdapat dalam bahan organik mempengaruhi kandungan $\mathrm{N}$ total tanah setelah masa inkubasi selama 6 minggu. Kotoran sapi yang diaplikasikan sebagai bahan campuran bahan organik adalah 2,5 ton per hektar; 3,33 ton per hektar dan 5,0 ton per hektar. Kotoran sapi (X) ini mempengaruhi kandungan $\mathrm{N}$-total tanah (Y), dan membentuk hubungan yang dapat diwakili dengan persamaan non-linier kuadratik

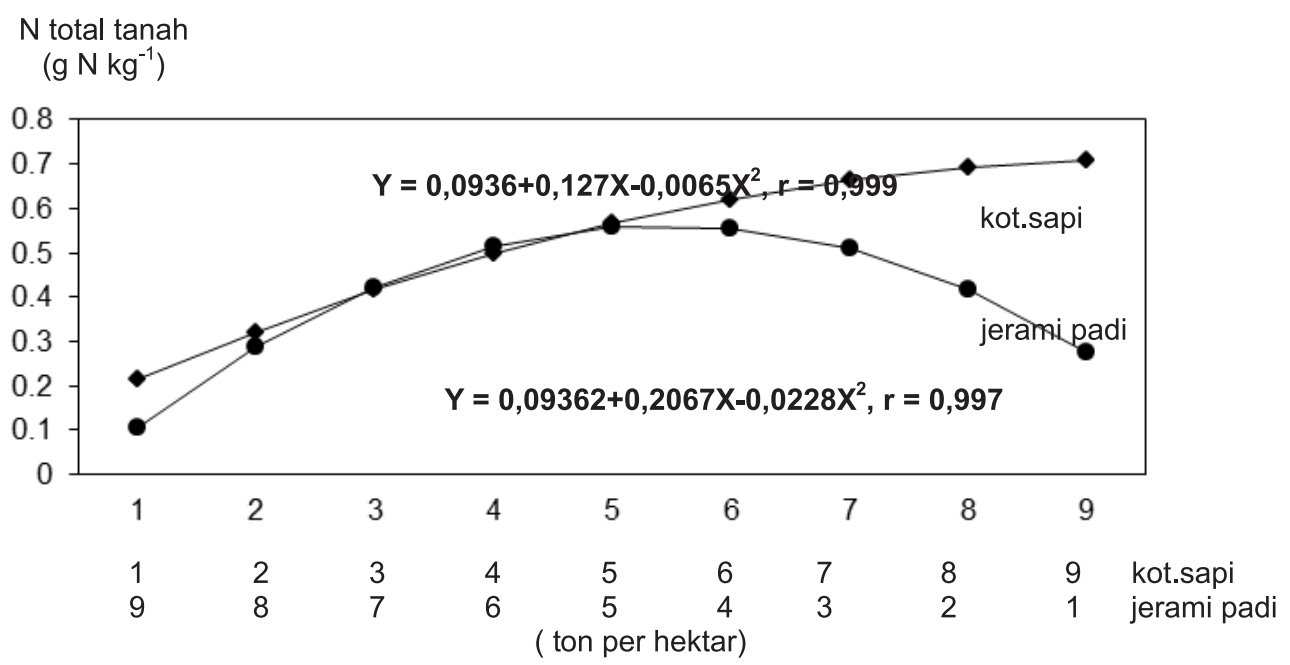

Gambar 3. Hubungan antara bobot sumber bahan organik dengan kandungan $\mathrm{N}$-total tanah setelah 6 minggu diinkubasikan. 
$\mathrm{Y}=0,0936+0,127 \mathrm{X}-0,0065 \mathrm{X}^{2}$. Gambar 3 juga memperlihatkan bahwa penambahan bobot kotoran sapi lebih dari 5 ton per hektar masih dapat me-ningkatkan kandungan $\mathrm{N}$ total tanah, dan mencapai maksimum kandungan $\mathrm{N}$ total tanah pada pemberian kotoran sapi sebanyak 9,7692 ton per hektar. Hal ini meng-akibatkan setiap peningkatan bobot kotoran sapi yang dimasukkan ke dalam tanah akan meningkatkan kandungan N-total. Sementara itu, bobot jerami padi yang diaplikasikan ke dalam pupuk bahan organik adalah 5 ton per hektar, 6,67 ton per hektar dan 7,5 ton per hektar. Jerami padi $(\mathrm{X})$ ini mempengaruhi kandungan $\mathrm{N}$-total tanah (Y), dan membentuk hubungan yang diwakili persamaan non-linier kuadratik Y=0,09362+0,2067X-0,0228X².

Bahan organik yang dipergunakan adalah campuran antara kotoran sapi dan jerami padi. Perubahan perbandingan bobot keduanya mempengaruhi kandungan N-total sebagaimana diperlihatkan dalam Gambar 3. Pada saat bobot jerami padi lebih besar dibanding bobot kotoran sapi, tanah dalam suasana aerob dan proses nitrifikasi ototropik dapat berlangsung sehingga produksi nitrat meningkat. Peningkatan bobot jerami padi ini menyebabkan tanah semakin porus sehingga memungkinkan terjadinya pelindian nitrat.

Hal ini juga disampaikan Sajjad,dkk. (2003) bahwa kehilangan besar $\mathrm{NO}_{3}$ - terjadi dari dalam tanah yang mengandung sisa tanaman yang sukar didekomposisikan. Pada saat bobot jerami padi lebih kecil dibanding bobot kotoran sapi, tanah memiliki daya retensi air lebih besar, sehingga pada saat - saat tertentu tanah dalam kondisi anaerob. Dalam kondisi anaerob ini bakteri anaerob fakultatif dapat menggunakan $\mathrm{NO}_{3}$ - menggantikan oksigen sebagai aseptor elektron (Batjes dan Bridges,1992).
Sajjad, dkk. (2003) melaporkan hubungan erat antara karbon mudah teroksidasi dan pengurangan $\mathrm{NO}_{3}$ - lewat denitrifikasi. Hal inilah yang diperlihatkan Gambar 3 bahwa pada saat bobot jerami padi berada di bawah maupun di atas kisaran 5 ton per hektar, dapat terjadi kehilangan nitrogen yang akhirnya menurunkan kandungan N-total tanah.

\section{SIMPULAN}

Dari hasil analisis dan pembahasan dapat disimpulkan bahwa :

1. Jumlah pelindian nitrat yang dihasilkan oleh perlakuan pupuk ZA lebih besar dibanding perlakuan pupuk Urea, sehingga Urea dapat direkomendasikan digunakan sebagai sumber hara $\mathrm{N}$ di lahan pasir pantai.

2. Perbandingan kotoran sapi - jerami padi 1:1 dapat menurunkan laju pencucian nitrat di lahan pasir pantai Kulon Progo.

\section{SARAN}

Berdasarkan hasil penelitian laboratorium yang menyatakan bahwa pupuk pupuk Urea dan perbandingan kotoran sapi - jerami padi 1:1 lebih sesuai diaplikasikan di tanah lahan pasir pantai, maka disarankan agar penelitian ini dapat diaplikasikan dalam skala lapangan dengan pertimbangan :

1. Perlu ditetapkannya berbagai dosis pupuk urea dan kompos kotoran sapi-jerami sapi (1:1) dalam budidaya komoditi pertanian yang cocok dibudidayakan di kawasan pantai Selatan Kulon Progo DIY.

2. Penelitian lapangan dapat memberikan gambaran yang lebih jelas tentang kinerja urea dan kompos kotoran sapi-jerami padi serta pengaruh lingkungan dalam meningkatkan produktivitas lahan pasir pantai Selatan Kulon Progo DIY 


\section{DAFTAR PUSTAKA}

Ayoola,O.T. and Adeniyan,O.N.2006. Influence of Poultry Manure and NPK on Yield and Yield Components of crops under Different Cropping Systems in South West Nigeria. African Journal of Biotechnology 5 (15):1386-1392

Bahr Amany,A., Zeidan,M.S. and Hozayn,M. 2006. Yield and Quality of Maize As Affected by Slow-release Nitrogen in Newly Reclaimed Sandy Soil. American-Eurasian Journal of Agriculture and Enviroment Sci. 1 (3): 239- 242

Baird,J.V.1990. Nitrogen Management and Water Quality.

http://www.soil.ncsu.edu/Publications/soilfacts/AG-439-02/ .Diakses Februari 2006

Baker, J.L. 2001. Limitations of Improved Nitrogen Management to Reduce Nitrate Leaching and Increase Use Efficiency. In Optimizing Nitrogen Management in Food and Energy Production and Environmental Protection; Proceedings of the 2nd International Nitrogen Conference on Science and Policy. The Scientific World I (S2): 10-16

Barbarick,K.A.2006. Nitrogen Sources and Transformation. http://www.ext.colostate.edu/Publications/. Diakses April 2006.

Batjes,S.A. and Bridges,E.M.1992. A Review of Soil Factors and Processes that Control Fluxes of Heat, Moisture and Greenhouse Gases. International Soil Reference and Information Center. Technical Paper 23. Wageningen: 70-73.

Bauder,T.A., Broner,I. and Waskom, R.M.2006. Nitrogen and Irrigation Management. http://agron.scijournals. Diakses Agustus 2006.

Belliturk,K. and Saglam,M.T. 2005. A Research on the Urea Hydrolisis Rate in the Soils of Thrace Region. Journal of Central European Agric. 6 (2): 107-114

Bohn,H.L., McNeal,B.L. and O'Connor,G.A.1985. Soil Chemistry 2nd ed. A Wiley Interscience Pub. John Wiley \& Sons.New York hal. 26-324

Blackmer,A.M. and Kyveryga,P.M. 2002. Fall Nitrification Happened. http://www.ipm.iastate.edu/ipm/iem/2002/1-21-2002/ nitrification/html.I Diakses Sepetember 2005.

Brady,N.C.2002. The Nature and Properties of Soils. Prentice-Hall of

India. Pvt.Ltd..New Delhi:315-338

Brooks,M.L. 2003. Effect of Increased Soil Nitrogen on the Dominance of Alien Annual Plants in the Mojavo Desert. http:/ /www.werc.usage.gov. Diakses September 2005.

Dobermann,A. and Fairhurst,T.H.2002. Rice Straw Management. Better Crops International vol. 16.

FA0.2005. The Importance of Soil Organic Matter, Key to Droughtresistant Soil and Sustained Food and Production. FAO of the United Nations. Rome. 95p.

Faesal, Najamuddin,A. dan Akil,M. 2006. Pengaruh Cara Pemberian dan Takaran Pupuk Kandang terhadap Hasil Biomas Tanaman Jagung. Balai Penelitian Tanaman Serelia. Maros. hal 5

Gunawan Budiyanto, Dja'far Shiddieq dan Muhammad Drajad.1997 Pengaruh Pemanfaatan Blotong terhadap Kejituan Serapan Kalium oleh Tanaman Jagung di Tanah Regosol Pantai Selatan Kulon Progo. Jurnal BPPS-UGM, 10 (3B): 427-444

Gunawan Budiyanto.2010. Teknologi Konservasi Lanskap Gumuk
Pasir Pantai Parangtritis Bantul DIY. Prosiding Simposium IImiah Nasional IALI 2010, IPB.

Cottenie,A., Verloo,M., Kiekens,L., Velghe,G. And Camerlynk,R. 1982. Chemical Analysis of Plants and Soils. Laboratory of Analitical And Biochemistry State University Ghent. Belgium and Instituut tot Aanbedlging van het Wetenschappelijk Onderzoek in Nijverheid en Landbouw. Brussel. page 63

Gehl,R.J., Schmidt,J.P., Maddux,L.D. and Gordon,W.B.2005. Corn Yield Response to Nitrogen Rate and Timing in Sandy Irrigated Soils. Agronomic Journal 97: 1230 - 1238

Gomez,K.A. and Gomez, A.A. 1984. Statistical Procedures for Agricultural Research. 2ed. An International Rice Research Institute Book. A Wiley-Interscience Pub. John Wiley \& Sons. Singapore: 7-118

Hansen,D.J., Blackmer,A.M., Mallarino,P. And Wuebker, M.A. 2004. Performance-Based Evaluation of Guidelines for Nitrogen Fertilizer Application after Animal Manure. Agronomy Journal 96(1): 34-41

Hasanudin.2003. Peningkatan Ketersediaan dan Serapan N dan P serta Hasil Tanaman Jagung melalui Inokulasi Mikoriza, Azotobacter dan Bahan Organik pada Ultisol.. Jurnal Ilmu-ilmu Pertanian Indonesia 5 (2): 83-89

Hassett,J.J. and Banwart, W.L. 1992. Soil and Their Environment. Prentice-Hall, Inc. New Jersey: 186-189, 241-244, 256-271.

Hesse,P.R. 1971. Soil Chemical Analysis. Chemical Publ. Co. New York. page149-169

Kara Emine Erman. 2000. Effects of Some Plant Residues on Nitrogen Mineralization and Biological Activity in Soils. Turkey Agronomic Journal 24 (2000): 457-480

Koesmaryono,Y. dan Handoko. 1995. Klasifikasi Iklim dalam Klimatologi Dasar. Editor Handoko. Pustaka Jaya. Jakarta. hal 170-173

Lovett,G.M., Weathers,K.C. and Arthur,M.A.2002. Control of Nitrogen Loss fron Forested Watersheeds by Soil Carbon:Nitrogen Ratio and Tree Species Composition. Journal of Ecosystem 5: 712-718

Munir,M.1996. Tanah Tanah Utama Indonesia. Karakteristik, Klasifikasi dan Pemanfaatannya. Pustaka Jaya. Jakarta: 329-330.

Mowidu.2001. Peranan Bahan Organik dan Lempung terhadap Agregasi dan Agihan Ukuran pori pada Entisol. Tesis Pascasarjana UGM. Yogyakarta.

Nakamura,K.,Harter,T.,Hirono,Y,,Horimo,H. And itsuo.2004.Assessment of Rootzone Nitrogen Leaching as Affected by Irrigation and Nutrient Management Pacticess.http://vsj.scijournal.org/cgi/content/abstracts/3/4/ 1353. Diakses Desember 2005.

Nurudin,M. dan Siradz,S.A.2001. Survey Keragaman Jenis dan Populasi Tanaman Indigenous dalam hubungannya dengan beberapa Sifat Tanah Pantai Selatan D.I. Yogyakarta. Laporan Penelitian Universitas Gadjah Mada Yogyakarta.

Pemerintah Daerah Kulon Progo D.I.Y. 2003. Kabupaten Kulon Progo. www.kulonprogo.go.id. Diakses Maret 2006.

Polprasert Chongrak. 1996. Organic Wste Recycling. 2nd-ed. John Wiley and Sons. page 76-86

Rankin Mike.2006. Minimizing Nitrogen Losses for Corn. http:// www.uwex.edu/ces/crops/NLoss06.htm. Diakses Januari 2007. 
Rahn C.R., Bending,G.D., Turner, M.K. and Lillywhite,R.D. 2003. Management of N Mineralization from Crop Residues of High $\mathrm{N}$-content using Amandment Materials of Varying Quality. Journal of Soil Use and Management (19): 193-200.

Rowell,D.L. 1995. Soil Science Methods \& Applications. Longman Scientific \& Technical. London: 218-243.

Saito,M.T.1991. Soil Management for the Conservation of Soil Nitrogen. http://www.agnet.org/library/article/eb341,html. Diakses Desember 2005.

Sajjad,M.H., Azam,F. And Lodhi,A. 2003. Nitrogen Transformation in Soil Amended woth Different Plant Residues and Their Impact on Growth of Wheat. Pakistan Journal of Biological Sciences 6(9):805-813.

Schmitt.M.A., Randall,G.W. and Malzer,G.I. 1994. Best Management Practices for Nitrogen Use on Irrigated, Coarse-Textured Soil.

http://www.extension.umn. edu/distribution/cropsystem/ DC631.html. Diakses September 2005.

Soedarsono,J., Yuwono, T. dan Prijambodo, I.D. 1997. Nasib N-NH4 dan N-NO3 di dalam Tanah Gambut yang Mengalami Perubahan Aerasi Secara Periodik. Jurnal IImu Tanah dan Lingkungan. FPUGM. Yogyakarta Vol. I No. 1(1997): 19-23.

Stevenson, F.J. 1982. Humus Chemistry. A Wiley Interscience Publication. U.S. of Amerika: 100-102; 241-244.

Sudihardjo, Suratman, Prihantini,T. dan Ritung,S. 2000. Lahan Pantai dan Pengembangannya dalam Sumberdaya Lahan Indonesia dan Pengelolaannya. Pusat Penelitian Tanah dan Agroklimat. Badan Penelitian dan Pengem-bangan Pertanian. Departemen Pertanian.Bogor: 97-126.

Sungkono. 1997. Peran Lahan Marginal dalam Mendukung Stabilitas Swasembada Pangan. Makalah disampaikan dalam Seminar Ikatan Senat Mahasiswa Pertanian Indonesia se Jawa Bali, 8 Maret 1997. Yogyakarta.

Sutoro, Soelaeman,Y. dan Iskandar. 1988. Budidaya Tanaman Jagung dalam Jagung. Badan Penelitian dan Pengembangan Pertanian. Pusat Penelitian dan Pengembangan Tanaman Pangan.Bogor: 49-66.

Wolkwoski, R.P., Kelling,K.A. and Bundy,L.G.2006. Nitrogen Management on Sandy Soils. http:// s142412519.onlinehome.us/uw/pdfs/A3634.pdf. Diakses September 2006.

White,J.R. and Reddy,K.R. 2003. Nitrification and Denitrification Rates of Evergludes Wetland Soil along a PhosphorousImpacted Gradient. Journal of Environmental Quality (32): 2436-2443.

Witkowska-Walczak, Bieganowski, A. and Rovdan,E. 2002. WaterAir Properties in Peat, Sand dan Their Mixtures. International Agrophysics 16: 313-318.

Yin,X., Foster,N.W. and Arp,P.A.1993. Solution Concentration of Nutrient lons below the Rooting Zone of a Sugar maple-stand: Relations to Soil Moisture, Temperature and Season. Canadian Journal of Forest Res.(23): 617-624. 